\title{
THE INFLUENCE OF THE OFFER OF ANIMATION PROGRAMS ON CUSTOMER SATISFACTION AND LOYALTY
}

Preliminary communication

UDK: 796/799:338.48](497.5)

JEL classification: L83, Z32

DOI: $10.17818 / \mathrm{DIEM} / 2022 / 1.9$

Accepted for publishing: July 8, 2021

\begin{abstract}
Tourist animation is a combination of services and content aimed at improving the overall experience of the tourist service. The purpose of animation activities is to provide the guest with more than anticipated, to outperform guests' expectations. The importance and significance of the added value that is provided to guests is increasingly emphasized. This paper was designed to overcome the deficit of research conducted in the field of tourist animation, especially the part related to the influence on customer satisfaction and loyalty. The main purpose of this research was to identify the factors of guest satisfaction that are positively related to the loyalty of guests in the hotel industry in the Republic of Croatia, through a review of the literature and the theory of guest satisfaction. Therefore, an empirical study was conducted in order to examine the impact of animation program offerings on guest satisfaction and loyalty from a manager's perspective using a qualitative study. From the collected and analyzed data, it is possible to presume that the quality of animation programs, animators, and communication with the guest has a positive effect on guest satisfaction. Also, it has been found that the offer of animation programs affects the return and loyalty of guests. Based on the results obtained at the end of the paper, guidelines for further development in this area are proposed. The contribution of this paper is reflected in the acquisition of new knowledge regarding the impact of animation programs on guest satisfaction and loyalty, with an emphasis on the comprehensiveness of animation programs.
\end{abstract}

Keywords: animation program, guest satisfaction, guest loyalty

\section{INTRODUCTION}

Animation, as an area of impact within the tourism activity and as a part of the tourist offer, was defined at the beginning of the industrial revolution and the first forms of tourist offer related to the time period from the beginning of the 20th century (Cerović, 2008, p. 45). Its forms and contents have changed over the years depending on changes in the social and economic systems in which tourist demand and supply are organized. 
Because of the dynamism and speed of today's life, people increasingly strive to find physical and mental peace that will result in rest and relaxation in order to prepare for rework. Rokicka-Habel et all. $(2016$, p. 158) state that for potential guests in the process of choosing a destination and accommodation, factors of excellence and special care (resulting from high-quality animation programs) are predominant in comparison with the traditional elements of sun, sand, sea.

Tourist animation is no longer perceived as an added value, but as a mandatory item that management must consider when planning further development. Franjić (2011, p. 122) considers that it is most appropriate to treat tourist animation as an element of a destination product that is essentially equal to food and accommodation. Sabol i Smajić (2013, p. 9) point out that the importance of tourist animation is confirmed by the fact that the tourist offer with targeted animation programs can be a decisive factor in choosing a destination and that it is viewed with equal importance as the choice of natural, cultural and gastronomic values. Tourist animation represents an important part of the tourist offer (Vidović, 2019, p. 51) with the main aim of satisfying the needs and wants of tourists as well as the increase in tourist consumption (Cerović, 2008, p. 56).

An analysis of existing research had identified a gap in the literature regarding the interplay of animation programs, guest satisfaction and loyalty. In the literature so far, the concept of tourist animation and its impact on tourist supply and demand have been insufficiently researched and processed, and therefore the purpose of this research has been twofold. To determine how animation programs affect the satisfaction of the guest and his loyalty and to enrich the field of scientific research of tourist animation. The main goal of the research was to determine which factors of animation programs have a positive impact on guest satisfaction and at the same time result in a re-visit of the guest. Accordingly, the following specific research objectives have been set:

- Identifying the factors of animation programs that have a positive impact on guest satisfaction,

- Identifying the impact of animation programs on the return and loyalty of the guests,

- Determining the existence of a connection between the satisfaction and loyalty of guests, related to the offer of animation programs.

With the development of tourism in the 50s of the 20th century and mass travel, the first forms of tourist animation appeared, which is why there was an attempt to explain the concept of animation in tourism. The emergence of today's general concept of animation in tourism defines animation as a human activity that has to do with the inner or mental reality of a man (Cerović, 2008, p. 46). A significant number of authors (Peković, S. et at., 2019; Albayrak, T. et al, 2016; Rokicka-Hebel, M. et al., 2016; Türkay, O. et al., 2013; Jakovlev, Z. et al., 2014; Mikulić, M., Prebežac, D., 2011; Cerović, Z., 2008; Garanin, N. I., 2004) define tourist animation as a part of the tourist offer that has the goal to meet the needs and wants of tourists pf the expected tourist experience, and with the aim of achieving tourist expenditure.

In the context of tourist animation as an economic activity, emphasis is placed on the organizational form of offering animation services at the level of a hotel facility or a tourist destination. The main role is played by the management of tourist animation whose task is to plan, organize, perform and control the execution of the animation program. Perković et. al $(2019$, p. 113) define animation programs as a specific range of services and content that complement and improve the overall range of tourist services.

Đorđević i Tomka (2011, p. 77) state how the concept of tourist animation can be observed in circular cycles of tourist-animation movements. 


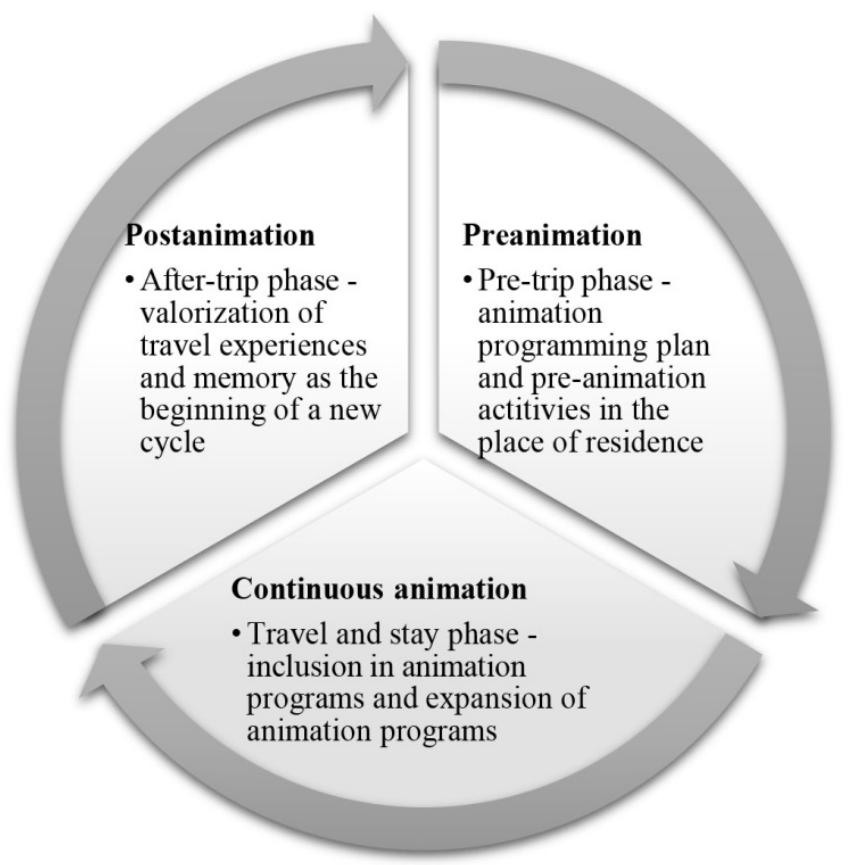

Source: author's processing according to: Đorđević, S., Tomka, D. (2011). Koncept lanca animacije u turizmu. Fakultet za sport i turizam. TIMS Acta 5, pp. 77.

Figure 1 Interactive circular cycle of tourist animation

All the aforementioned cycles of tourist animation are in an interactive relationship during the trip and the realization of animation activities. As the most important factor influencing the satisfaction of tourists, the cycle of continuous animation can be pointed out, which is also called the animation-tourist "anchor", and through which tourists experience tourist animation most intensively.

With the aim of measuring the impact of tourist animation according to Cerović (2008, p. $141)$, it is possible to apply two basic methods:

- financial presentation of effects (profit, quantity),

- $\quad$ non-financial presentation of effects (satisfaction, experience).

Financial effects are easier to measure because they are determined by monetary units, numbers and other physical indicators while the guest satisfaction and loyalty factors are far more complex and difficult to quantify and requires special measurement methods and techniques. Scientific research in the field of tourist animation that examined the impact of animation programs on customer satisfaction and loyalty (Sabol i Smajić, 2013; Vidović, 2019; Cerović, 2008; Rončević et al, 2019; Mikulić i Prebežac, 2011; Getz, 2005; Glinia et al., 2001; Jadrešić, 2001; Corbaci, 1993; Anderson i Mittal, 2000; Demir i Demir, 2015; Perović et al., 2018; Peković et al., 2019; Antunac, 2001; Olah, 2016) have served as a foundation for the concept of this research.

\section{THE INFLUENCE OF ANIMATION PROGRAMS ON GUEST SATISFACTION AND GUEST LOYALTY}

Animation programs in the tourist offer of the 21 st century are necessary and have been proven to have a significant impact on the choice of travel and vacation destinations (Sabol i Smajić, 2013, p. 9). In service occupations, including tourist animation, only the satisfaction of the guest is a measure of success. Cleas (2007, p. 45) points out that only satisfied consumers represent real, intangible, economic assets. According to the previous studies, the animation program offer has 
impact on the satisfaction of the guest (Markus et al., 2019; Peković et al., 2019; Perović et al, 2018; Albayrak, Caber i Öz, 2016; Cetin i Walls, 2015; Demir i Demir, 2015; Laškarin, 2015; Ababneh, 2013; Korkutata i Yılmaz, 2013; AbuKhalifeh i Mat Som, 2012; Mikulić i Prebežac, 2011; Türkay, Camarda i Badau, 2010; Cerović, 2008; Glinia et al, 2001; Glinia et al, 2001a; Jadrešić, 2001; Corbaci, 1993).

Because of the key role that guest satisfaction plays in the success of hotel businesses, Oh (1999, p. 68) points out that scientists have long explored tourists' perceptions of the quality of hotel attributes and their impact on overall customer satisfaction (OCS - overall customer satisfaction). Mikulić and Prebežac (2011, p. 688) tried to categorize the attributes of the hotel animation program and their results indicated that the diversity of activities is a fundamental determinant in the overall satisfaction of tourists. Vovk i Vovk $(2017$, p. 70$)$ found that the benefits of tourist animation stem from enriching guests 'travel and providing them with an unforgettable experience, while Karadzhova and Angelov $(2018$, p. 22) confirmed a positive correlation between tourist animation and creating a sense of connection to the destination or hotel facility where they stayed. The purpose of all animation activities is to create a vibrant surrounding that allows tourists to socialize, hang out, as well as an active and fun vacation through learning about different cultures and customs, and there is no doubt that such a tourist offer will not result in a positive tourist satisfaction. Sotiriadis $(2014$, p. 45$)$ points out that the quality of animation programs is also an important factor in achieving the general satisfaction of tourists. According to Laškarin $(2015, \mathrm{p}$. 21), the levels of guest satisfaction may differ depending on the relationship between service quality and guest expectations

According to research by Albayrak et al. $(2016$, p. 9$)$ it has been proven that the quality of animation services has a significant effect on the overall satisfaction of the guest. Mikulić and Prebežac (2011, p. 695) have defined the factor of activity diversity as a key determinant of satisfaction with animation programs. Perković et al. $(2019$, p.113) in their results of the research confirmed a statistically positive and significant connection between tourist satisfaction and the competencies of animators. It can be concluded that the expertise and education of the animator is a factor in achieving the quality of the animation program and in a positive correlation with that and achieving guest satisfaction with the animation program. As stated by Türkay et al. (2014, p. 12), these are the reasons why animation programs must be of high quality, designed to be appropriate to the time and place of performance with staff who have adequate knowledge, experience and manners that are desirable to guests.

By taking into perspective of feeling as informations, people use an already existing positive impact as a source of information that creates a positive image of a particular destination. Liu $(2020$, p. 3) argues that it reflects a deep commitment that the guest will consistently respond to the desired tourism product in the future. Previous guest loyalty research is mostly based on the aspect of a tourist destination, but certain laws can also be applied to the segment of tourist products. The purpose of adapting the tourist offer to the wants and needs of guests is to achieve guest loyalty. The same concept of thinking is applied to animation programs which, by constantly harmonizing with the requirements of tourist demand make them attractive and high quality, while at the same time building a bond of loyalty with the users of animation programs. Maričić $(2005$, p. 489) states that the benefits that are realized from loyal guests are numerous and some of them can be singled out:

loyalty to a company, product or a service

promotion of the company, product or a service by the guest to other potential guests supporting the positive so-called word of mouth image.

Numerous authors have confirmed the existence of a positive link between guest loyalty and the economic success of the hotel (Reichheld and Sasser, 1989, p. 106; Almeida-Santana and Moreno-Gil, 2008, p. 246; Oliver, 1999, p. 43). The optimal way to determine the impact of animation programs on guest loyalty is to analyze horizontal loyalty (Almeida-Santana and Moreno-Gil, 2018, p. 252). In this way, the factors of guest loyalty can be defined depending on the 
needs and wishes of the guest. Previous research emphasizes that there are various factors that motivate tourists to return to the same destination, and some of them are: guest satisfaction and perceived quality, safety and reduced risk, novelty, competitiveness of the destination and its image and past guest experience (Perović et al, 2007 , pp. 1858). All of the above can be directly linked to the offer of animation programs.

Satisfaction and loyalty of guests in the hotel industry are recognized as the dominant success factor in this sector. Today's guest who is experienced and picky knows what kind of service he wants and what kind of animation program he is looking for. Numerous authors in their previous research have confirmed the connection between guest satisfaction and their loyalty (Schlesinger, et al, 2020, p. 8; Ka and Lai, 2019, p. 118; Gallarza, et al, 2019, p. 264; Türkay, et al, 2013, p. 10; Da Costa Mendes, et al, 2010, p. 121).

The cause-and-effect relationship between the satisfaction and loyalty of guests conditioned by the offer of animation programs in hotels has been dealt with by research conducted so far (Cervera-Taulett i Pérez-Cabañero, 2020; Arteaga, i Gil-Saura, 2019; Ka i Lai, 2019; Cetin i Walls, 2015; Laškarin, 2015; Türkay, Korkutata i Yılmaz, 2013; AbuKhalifeh i Mat Som, 2012; Schlesinger, Gallarza, Da Costa Mendes et al., 2010; Oliver, 1999). Given the complexity of this connection, there is still a need of combining these dimensions and simultaneous research in order to obtain a more comprehensive picture of the importance of adapting animation programs to the wishes and needs of today's tourists.

Analyzing the previous research in the graphic presentation that follows, the relationship of tourist animation to the satisfaction and loyalty of the guest is shown.

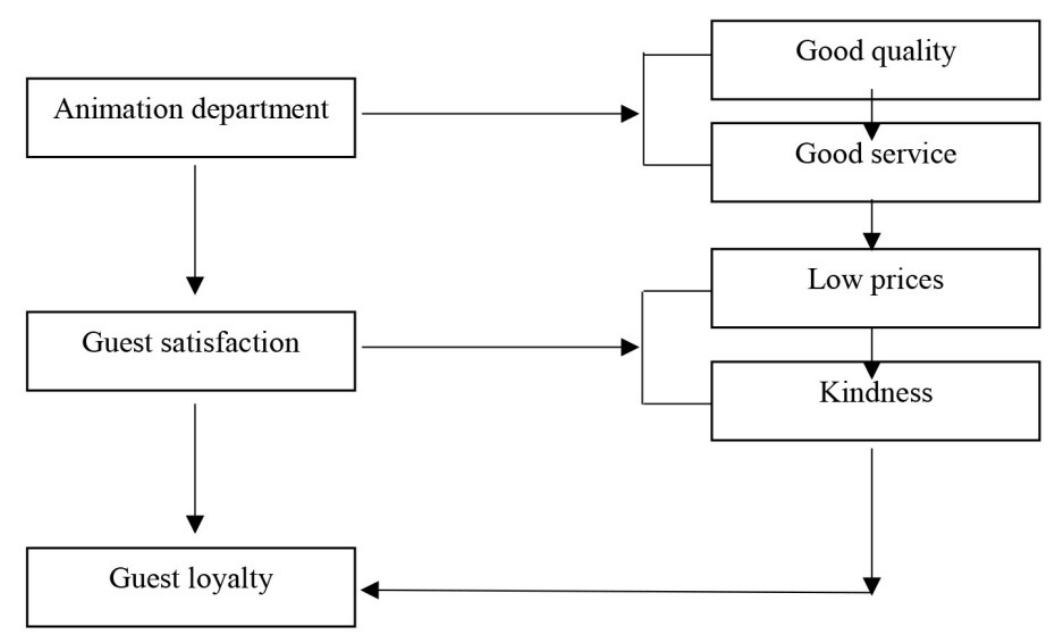

Source: author's processing according to: AbuKhalifeh, A. N., Mat Som, A. P. (2012). Guest satisfaction and loyalty in food and beverage service department in the hotel industry. 2nd International Conference on Management Proceeding. Malaysia. str. 999.

Figure 2 The relationship of the animation department to the satisfaction and loyalty of guests

It can be concluded that the quality of the program and the animation team with reasonable prices and the kindness of the staff can result in guest satisfaction and directly affect his loyalty. 


\section{ANALYSIS OF THE IMPACT OF THE OFFER OF ANIMATION PROGRAMS ON GUEST SATISFACTION AND LOYALTY IN HOTEL FACILITIES OF THE REPUBLIC OF CROATIA}

The growth of international competition in the hospitality and hotel industry makes it necessary to measure and understand how guests can be satisfied with the services provided to them. Some forms of tourist services, such as animation programs, have been insufficiently researched in the context of guest satisfaction and loyalty. The fact that the field of tourist animation is insufficiently researched is potentially reflected in the opinion that animation programs do not have a strong enough influence on the overall tourist satisfaction and subsequent behavior.

Previous research in the scientific literature has mainly focused on the importance of guest satisfaction or loyalty for the success of the animation program, but from a tourist perspective. Numerous researches deal with the influence and importance of animators for success and positive effect on the guest (Peković, S. et al., 2019; Rokicka-Hebel, M., et al., 2016; Jakovlev, Z. et al, 2014; Sabol, V. i Smajić, J., 2013; Mikulić, J. i Prebežac, D., 2010; Ivkov, A. i Stamenković, I., 2008; Tekin, A., 2006). Research in which the influence of satisfaction, guest loyalty and animation programs as a whole that is offered to the guest is interrelated, is present to a much lesser extent. Demir and Demir $(2015$, p. 43) present the results of their research according to which managers and hotel guests share the belief in the significant role and impact of animation programs on guest satisfaction. In order to deepen the mentioned topic, this research represents a step forward in previous research due to the fact that it is based on the opinions and suggestions of the managers and managers of hotel animation..

In order to achieve the set goals, empirical research was conducted. A structured questionnaire and a semi-structured online interview were used as a measuring instrument. The basic set of research is presented by managers and directors of hotel animation of 6 hotel companies in the Republic of Croatia. The research was conducted in the period from April to July 2020 in the Republic of Croatia. The questionnaire was delivered to the respondents online and referred to the data on hotel work, the respondents' opinion on the impact of animation programs on guest satisfaction and loyalty, and the opinion on the impact of different characteristics of animation programs on satisfaction and loyalty. Semi-structured interviews with respondents were conducted in an online environment and the questions were asked in a way that gives a certain degree of freedom in providing answers. The analysis of the results included 23 fully completed questionnaires and 11 online interviews.

The most represented respondents in the survey were 3-star (35\%) and 4-star (35\%) hotels. Out of a total of 22 respondents, $43 \%$ of them are employed as hotel directors, and $26 \%$ of them are employed as animation department manager and animation department directors. The largest percentage of respondents (39\%) have been working in this position for 4-7 years. In the animation department, $26 \%$ of respondents have also worked for 4-7 years, while only one respondent stated that they have been working in the animation department for more than 15 years. 


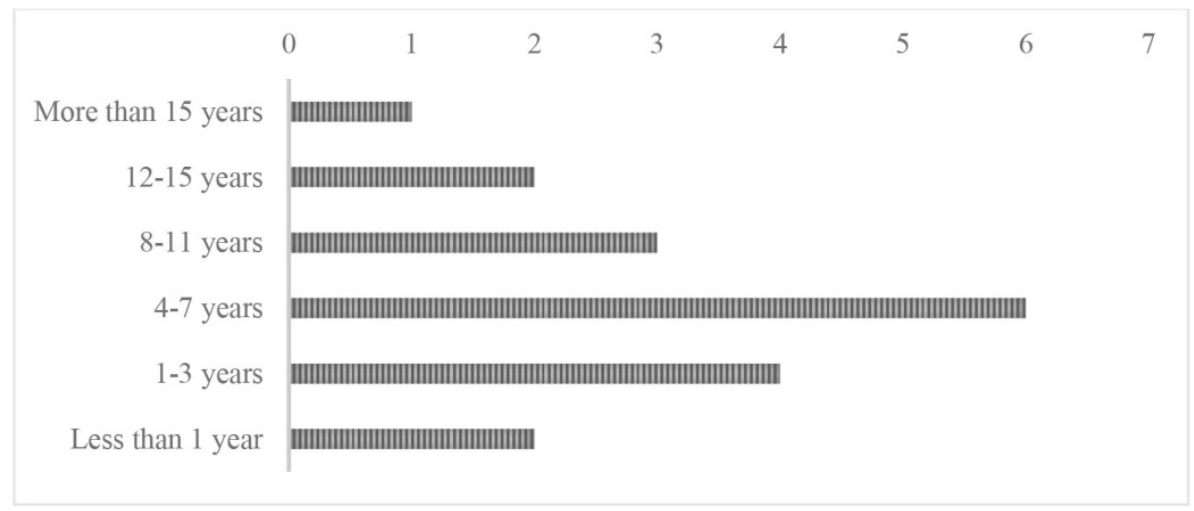

Source: author's research, May 2020.

Figure 3 Years of work in the animation department

According to the managers of the leading hotel companies in the Republic of Croatia, animation programs mainly increase the level of general satisfaction of guests in the hotel facility, and consequently their loyalty. The following table presents in more detail the opinion of respondents on the impact of animation programs on guest satisfaction and loyalty.

Table 1 Characteristics of animation programs that have a positive impact on guest satisfaction and loyalty

\begin{tabular}{lcccc}
\hline \multirow{2}{*}{ CLAIM } & \multicolumn{2}{c}{ GUEST } & \multicolumn{2}{c}{ GUEST LOYALTY } \\
& \multicolumn{2}{c}{ SATISFACTION } & \multicolumn{2}{c}{ S.D. } \\
\hline The impact of the quality of animation programs & A.S. & S.D. & A.S. & 1.4 \\
The impact of personalization of animation programs & 5.8 & 1.5 & 5.7 & 1.3 \\
The impact of social interaction stimulated by animation programs & 5.8 & 1.1 & 5.7 & 1.1 \\
The impact of continuous innovation of animation programs & 6.4 & 0.6 & 6.2 & 0.7 \\
The impact of the diversity of the offer of animation programs & 6.0 & 1.3 & 5.7 & 1.3 \\
Impact of the hotel's competitive advantage due to the offer of & \multirow{2}{*}{6.1} & 0.8 & 6.0 & 1.3 \\
\hline animation programs & & & & \\
\hline
\end{tabular}

Source: author's research, May 2020.

Of the total number of respondents, $47 \%$ believe that the quality of animation programs affects the satisfaction (5.8) of guests. Due to the generated and uniform offer, taylor-made offers and programs specifically designed for a specific target group are becoming increasingly important. According to the managers' opinion, the personalization of animation programs is important, that is it has an impact on the satisfaction (5.8) of guests. This is justified by the fact that people like to get value for money, but they also like to feel special. In addition to the quality and adaptation of animation programs to the types of guests, the research showed that the continuous innovation of the offer of animation programs, according to the respondents, has the greatest impact (6.4) on guest satisfaction. The offer diversity segment is the second characteristic (6.0) that respondents point out as important in creating guest satisfaction.

Respondents see certain characteristics of animation programs as important for influencing the increase in guest loyalty. The range of ratings ranges from 5.7 to 6.2 , and according to the results, the most important are the continuous innovation of animation programs (6.2) and, as in the case of guest satisfaction (6.1), the competitive advantage of the hotel (6.0). 
The influence of animation programs on guest satisfaction can be observed through different segments, so the respondents in the continuation of the research have defined which are the segments in which animation programs have the greatest impact on guest satisfaction.

Table 2 The influence of animation programs on guest satisfaction

\begin{tabular}{|c|c|c|}
\hline $\begin{array}{l}\text { CLAIM } \\
\text { Influence of animation programs on guest satisfaction in segments of }\end{array}$ & A.S. & S.D. \\
\hline Entertainment & 6.3 & 1.1 \\
\hline Relaxation & 5.7 & 1.3 \\
\hline Socialization & 5.7 & 1.2 \\
\hline Active rest & 6.2 & 1.1 \\
\hline Recreation & 6.2 & 1.2 \\
\hline Commitment to self (yoga, meditation, spa, wellness) & 5.3 & 1.4 \\
\hline Education (children's animation, team building programs) & 6.1 & 1.0 \\
\hline $\begin{array}{l}\text { The impact of animation programs on increasing the level of general guest } \\
\text { satisfaction in a hotel facility }\end{array}$ & 5.9 & 0.9 \\
\hline
\end{tabular}

Source: author's research, May 2020.

According to the results of the research, $61 \%$ of respondents have confirmed that animation programs in the entertainment segment have the greatest impact on guest satisfaction (6.3). The following are the segments of active rest (6.2) and recreation (6.2). According to the respondents, the animation programs that result in the highest level of guest satisfaction are evening (6.5) and daily animation for children (6.4), education (5.4) and evening animation for adults (5.3), as shown in the table below.

Table 3 Animation programs that result in the highest level of guest satisfaction

\begin{tabular}{ccc}
\hline CLAIM & A.S. & S.D. \\
\hline Daily animation for adults & 5.0 & 1.2 \\
Evening animation for adults & 5.3 & 1.3 \\
Daily animation for children & 6.4 & 1.1 \\
Evening animation for children & 6.5 & 1.0 \\
Wellness and spa programs & 4.0 & 1.5 \\
Team building programs & 4.6 & 1.8 \\
Education (children's animation, team building programs) & 5.4 & 1.3 \\
\hline
\end{tabular}

Source: author's research, May 2020.

High values of the arithmetic mean of all programs with small mutual deviations indicate a very high importance of all animation programs, and related to their impact on guest satisfaction.

In addition to the structured questionnaire, as stated, a semi-structured interview survey was conducted on a sample of 11 respondents where the focus of the research was on determining guest satisfaction and loyalty while identifying important aspects of animation that can improve business and improve the tourist offer.

When asked about the estimate of the increase in the number of arrivals / overnight stays in the hotel by introducing animation programs, the respondents expressed this percentage increase in different values. These values ranged from $15 \%$ to $75 \%$ for hotels where the target group is guests of families with children whose interest in the hotel is growing in proportion to the quality of the offer of animation facilities. One of the respondents pointed out that the introduction 
of animation programs had a more qualitative effect on guest satisfaction than quantitative because satisfied guests will create a good promotion of the hotel offer.

As previously shown in the results of the survey questionnaire, the personalization of animation programs is increasingly important for attracting old and new guests. Hotel companies whose employees participated in the research personalize animation programs in different ways, but all through the adaptation of the program to the structure of guests (family guests - season, couples and groups of adults - pre and post season). Personalization is enhanced depending on the age group of guests, market trends, but also weather conditions. Respondents state that personalization is approached in several ways: by multilingual communication, listening to the needs of guests and acting accordingly, meeting guests, relaxed and personal approach, additional offer (birthdays, anniversaries, special occasions). Respondents emphasized that personalization leads to the creation of a distinction between animation programs among different hotel companies, which results in advantages in the tourism market. Respondents who participated in the interview pointed out that they design their animation programs depending on market trends and the needs of guests.

Many respondents expressed the importance of selection, development and education of staff and the quality of the programs themselves as key factors in achieving guest satisfaction with animation programs. One of the respondents mentioned the personal impression that each employee can leave on guests with a unique performance of a particular program, effort, character. The research has established that the development of animation content is constantly encouraged by implementing new technologies, modern educational and development practices and new market trends. One of the respondents also mentioned the importance of the infrastructure of children's and sports facilities, which is extremely modern and includes a kitchen, nintendo wii, computers, and the other

When asked about the use of CRM in the function of personalization of animation programs, only $20 \%$ of respondents confirmed this statement. These hotel companies use written and digital (online) surveys and social networks to get feedback from guests. By analyzing sites such as Booking.com and Tripadvisor, possible errors are identified and animation programs are corrected in order to achieve maximum guest satisfaction and loyalty. Through the research, several respondents stressed the importance of entering information about the guest in his profile cards so that a personalized offer could be prepared for his next arrival.

\section{CONCLUSIONS}

The modern tourist product is not only accommodation, gastronomy and occasional free or cultural activities, it includes many additional services, including tourist animation. Nowadays, nothing is fixed and static, and so is guest satisfaction, which is dynamic, changeable and complex in nature. Animation programs as a platform that can meet the requirements of constant variability, innovation, are designed to create a "more than expected" experience for guests. Their direct role is to achieve guest satisfaction and experience, while creating a sense of loyalty. Research has confirmed how animation programs through multiple variables can affect guest satisfaction. The quality and continuous innovation of the offer of animation programs, personalization and encouragement of social interaction, diversity of the offer and richness of content have proven to be the main factors in achieving guest satisfaction through animation programs. The paper proves the cause-and-effect relationship between guest satisfaction with animation programs and their loyalty. This connection is especially emphasized by the results of research that in the same way valorize the factors of continuous innovation of animation programs and personalization of animation programs to achieve guest satisfaction and loyalty. 


\section{REFERENCES}

Al-Ababneh, M. (2013). Service Quality and its Impact on Tourist Satisfaction. Interdisciplinary Journal of Contemporary Research in Business, 4, 12.

Albayrak, T., et al. (2016). Assessing Recreational Activities' Service Quality in Hotels: An Examination of Animation and Spa \& Wellness Services. Journal of Quality Assurance in Hospitality \& Tourism. https://doi.org/10.1080/1528008X.2016.1208550

Almeida-Santana, A., Moreno-Gil, S. (2018). Understanding tourism loyalty: Horizontal vs. destination loyalty. Tourism Management 65, pp. 245-255. https://doi.org/10.1016/j.tourman.2017.10.011

Anderson, E. W., Mittal, V. (2000). Strengthening the satisfaction-profit chain. Journal of Service Research, 3, pp. 107-120. https://doi.org/10.1177/109467050032001

Camarda, A., Badau, D. (2010). Entertainment and sports animation effects and benefits. Ovidius University Annals, Series Physical Education and Sport/Science, Movement and Health, 10(2), pp. 858-863.

Cerović, Z. (2008). Animacija u turizmu. Opatija: Fakultet za menadžment u turizmu i ugostiteljstvu.

Cetin, G., Walls, A. (2016). Understanding the Customer Experiences from the Perspective of Guests and Hotel Managers: Empirical Findings from Luxury Hotels in Istanbul, Turkey. Journal of Hospitality Marketing \& Management, 25, 4. https://doi.org/10.1080/19368623.2015.1034395

Cleas, F. (2007). The Satisfied Consumer. Palgrave/Macmillan, New York.

Corbaci, A. (1993). The usage of Turkish cultural motives for leisure activities in holiday villages. Yayınlanmamıs, doktorski rad. Istanbul University, Istanbul, Turkey.

Da Costa Mendes, J. et al. (2010). The tourist experience: Exploring the relationship between tourist satisfaction and destination loyalty. Tourism, 58, 2, pp. 111-126.

Demir, M., Demir, ş. ş. (2015). The evaluation of hotel animation service from managers and tourists' perspective. International Journal of Social Sciences and Education Research, 1 (1), pp. 35-48.

https://doi.org/10.24289/ijsser.106394

Đorđević, S., Tomka, D. (2011). Koncept lanca animacije u turizmu. Fakultet za sport i turizam. TIMS Acta 5, pp. 70-79.

Franjić, R. (2011). Animator kulturnog turizma kao menadžer doživljaja. Montenegrin Journal of Economics, 7, 2, pp. 121.-127.

Gallarza, M. G., et al. (2019). Customer value in tourism and hospitality: Broadening dimensions and stretching the value-satisfaction-loyalty chain. Tourism Management Perspectives 31, pp. 254-268.

https://doi.org/10.1016/j.tmp.2019.05.011

Garanin, N. I. (2004). Menedzhment turistskoi i gostinichnoi animatsii: [ucheb. posob.] / N.I. Garanin, I.N. Bulygina. Moscow: Sovetskii sport, pp. 128.

Getz, D. (2005). Event management and event tourism. (2nded.). New York: Cognizant Communications Corporation. https://doi.org/10.1016/j.tourman.2004.02.008; https://doi.org/10.1016/S0261-5177(04)00032-9

Glinia, E. et al. (2001a). Review on the management of animation in major hotel enterprises in Greece. Proceedings of the 9th Congress of Physical Education \& Sports. Komotini.

Glinia, E., et al. (2004). Hotel Animation and Professional Perspectives in Greece. Tourism Today, pp. 123-130.

Ivkov, A., Stamenkovic, I. (2008). The Implementation of the "Bologna process" into the subject of animation in tourism, as a significant part of the hotel industry products promotion. Tourism and Hospitality Management, 1, pp. 129-140.

Jadrešić, V. (2001). Turizam u interdisciplinarnoj teoriji i primjeni: zbornik istraživanja, Školska knjiga, Zagreb. Jakovlev, Z. et al. (2014). Animator's Roles in Enriching the Content of Tourist Stay. Journal of Tourism and Hospitality Management, ISSN 2328-2169, 2, 3, pp. 133-139. https://doi.org/10.17265/2328-2169/2014.03.005

Ka, I., Lai, W. (2019). Hotel image and reputation on building customer loyalty: An empirical study in Macau. Journal of Hospitality and Tourism Management 38, pp. 111-121. https://doi.org/10.1016/j.jhtm.2019.01.003

Karadzhova, Z., Angelov, A. (2018). The animation - an attraction and/or a need (The Case of Company BVS Entertainment Ltd.). International Journal of Innovative Technologies in Economy, 2 (14), pp. 20-27.

Laškarin, M. (2015). Menadžment zadovoljstva gosta u hotelijerstvu primjenom programa loyalty, doktorski rad. Sveučilište u Rijeci: Fakultet za menadžment u turizmu i ugostiteljstvu. 
Liu, Y. et al. (2020). How does brand loyalty interact with tourism destination? Exploring the effect of brand loyalty on place attachment. Annals of Tourism Research 81, pp. 2-13. https://doi.org/10.1016/j.annals.2020.102879

Maričić, B. (2005). Ponašanje potrošača. Centar za izdavačku djelatnost Ekonomskog fakulteta. Beograd.

Markus, Z. et al. (2019). Assessing Tourist Revisit Intention Through the Sport-Recreational Services Offered. Business Systems Research, 10 (2), pp. 1-10. https://doi.org/10.2478/bsrj-2019-023

Mikulić, J., Prebežac, D. (2011). Evaluating hotel animation programs at Mediterranean sun-and-sea resorts: An impact-asymmetry analysis. Tourism Management 32, pp. 688-696. https://doi.org/10.1016/j.tourman.2010.05.026

Mossberg, L. (2007). A marketing approach to the tourist experience. Scandinavian Journal of Hospitality and Tourism, 7, 1, pp. 59-74. https://doi.org/10.1080/15022250701231915

Nimer AbuKhalifeh, A., Puad Mat Som, A. (2012). Guest satisfaction and loyalty in food and beverage service department in the hotel industry. 2nd International Conference on Management, pp. 996-1008.

Oh, H. (1999). Service quality, customer satisfaction, and customer value: a holistic perspective. International Journal of Hospitality Management, 18, pp. 67-82. https://doi.org/10.1016/S0278-4319(98)00047-4

Olah, I. (2016). The significance of animation in the tourism of Hungary. Agricultural Bulletin of Stavropol Region. Quarterly Research and Practice Journal. 4(24)/2 Supplement, pp. 64-66.

Oliver, R. L. (1999). Whence Consumer Loyalty? Journal of Marketing: Fundamental Issues and Directions for Marketing, 63, pp. 33-44. https://doi.org/10.2307/1252099

Peković, S. et al. (2019). The Influence of Animation Programmes on Tourists' Satisfaction: The Role of Animators. Sport Mont 17, 3, pp. 113-115. https://doi.org/10.26773/smj.191020

Perović, $Đ$. et al. (2018). The antecedents of tourist repeat visit intention: systemic approach. Kybernetes, 47, 9, pp. 1857-1871. https://doi.org/10.1108/K-12-2017-0480

Reichheld, F., Sasser, W. (1989). Zero Defections: Quality Comes to Service. Hardvard Business Review, 68(5), pp. 105-111.

Rokicka-Hebel, M. et al. (2016). The professional profile of a leisure time animator in tourism and recreation services. Balt J Health Phys Act., 8(4), pp. 157-168. https://doi.org/10.29359/BJHPA.08.4.17

Rončević, A. et al. (2019). Development potential analysis of rural tourism in the Samobor area. 42nd International Scientific Conference on Economic and Social Development - London, pp. 12-13.

Sabol, V., Smajić, J. (2013). Animacijski programi za djecu u funkciji obogaćenja turističke ponude Republike Hrvatske. Međimursko veleučilište u Čakovcu.

Schlesinger, W., et al. (2020). Exploring the links between destination attributes, quality of service experience and loyalty in emerging Mediterranean destinations. Tourism Management Perspective. https://doi.org/10.1016/j.tmp.2020.100699

Shivers J. S. (1981). Leisure and recreation concepts: a critical analysis. London: Allyn and Bacon, pp. 216.

Sotiriadis, M. D. (2014). Management and Operational Issues of Animation Services in Resort and All-inclusive Hotels: Evidence from Greece. Mediterranean Journal of Social Sciences, 5, 20, pp. 692-698. https://doi.org/10.5901/mjss.2014.v5n20p692

Tekin, A. (2006). Sport tourism - an animation perspective. Journal of Sport Tourism, 9(4), pp. 317-322. https://doi.org/10.1080/1477508052000341850

Türkay, O., et al. (2013). Does Animation Services Really Matter? Place of Animation Services in the Perceived Quality-Overall Satisfaction Model. Journal of TOurism and Services 9, 16, pp. 14-30. https://doi.org/10.29036/jots.v9i16.40

Vidović, A. (2019). Guest Animation in Tourism Work Entrepreneurial Venture. Journal of Economics, Trade and Marketing Management, 1, 2, pp. 51-59. https://doi.org/10.22158/jetmm.v1n2p51

Vovk, I., Vovk, Yu. (2017). Development of family leisure activities in the hotel and restaurant businesses: Psychological and pedagogical aspects of animation activity. Economics, Management and Sustainability, 2(1), pp. 67-75. https://doi.org/10.14254/jems.2017.2-1.6 